\title{
Molecular Docking Analysis of Some Bioactive Molecules of Cistus incanus Against SARS CoV-2
}

\author{
Sakine Kübra ÇELİK ${ }^{1}$, Elvan ÜSTÜN²*
}

\begin{abstract}
Coronavirus disease affects all the world with the pandemic way that we are still living. The fight against the disease continues with vaccination all over the world. Considering the protection time and the difficulties in attaining the vaccine, in order to be successful in fighting against the disease, we need drugs that enable to kill or hinder replication of the viruses. In drug studies, after analyzing the effect of phytochemicals on the viruses, isolated phytochemical is modified in order to synthesize a more effective molecule. It is not possible to analyze the anti-viral activity of each isolated molecule by in-vitro methods, and in-silico methods can help to overcome this problem. Cistus incanus is a plant whose anti-viral activity has been confirmed by previous trials on many viruses. In this study, the interaction of myricetin 3-Ohexoside, myricitrin, quercitrin and kaempferol 3-O-rutinocide which were detected in the Cistus incanus, were analyzed by molecular docking methods with papain-like protease and main protease crystal. Strong H-bonds were detected between the investigated molecules and papain-like protease and main protease.
\end{abstract}

Keywords: COVID-19, Papain-Like Protease, Cistus incanus, Molecular Docking

\section{Cistus incanus'un Bazı Biyoaktif Moleküllerinin SARS CoV-2 ye Karşı Moleküler Doking Analizi}

\section{$\ddot{\mathbf{O z}}$}

Koronavirüs hastalığı, halen yaşanmakta olan pandemik süreçle bütün dünyayı etkilemektedir. Hastalık ile mücadele tüm dünyada, aşılama çalışmaları ile devam etmektedir. Koruyuculuk süresi ve aşıya ulaşmadaki zorluklar düşünüldüğünde, hastalık ile mücadelede başarılı olunabilmesi için, virüsün öldürülmesi ya da replikayonunun engellenmesini sağlayan ilaçlara ihtiyaç vardır. İlaç çalışmalarında fitokimyasalların virüs üzerine etkisinin incelenmesinin ardından, daha etkili moleküllerin sentezlenebilmesi için izole moleküllerin modifiye edilmesi yöntemi uygulanır. İzole edilen her bir molekülün anti-viral aktivitesinin in-vitro yöntemlerle analizi mümkün değildir ve bu sorunun üstesinden gelmek için insilico yöntemler yardımcı olabilir. Cistus incanus daha önce pek çok virüsün denemeleri yapılarak anti-viral aktivitesi teyit edilmiş bir bitkidir. Bu çalışmada içerik analizi sonrasında Cistus incanus'da tespit edilen myricetin 3-O-hexoside, myricitrin, quercitrin ve kaempferol 3-O-rutinocide moleküllerinin papain-like protease and main protease ile etkileşimi moleküler doking yöntemleri ile analiz edilmiştir. Analizlerin sonucunda incelenen moleküller ile papain-like protease ve main protease arasında güçlü H-bağları tespit edilmiştir.

Anahtar Kelimeler: COVID-19, Papain-Like Proteaz, Cistus incanus, Moleküler Doking

\footnotetext{
${ }^{1}$ Ordu University, Department of Chemistry, Faculty of Art and Science, Ordu, Turkey, skubracelk@gmail.com

${ }^{2}$ Ordu University, Department of Chemistry, Faculty of Art and Science, Ordu, Turkey, elvanustun77@gmail.com
}

${ }^{1}$ https://orcid.org/0000-0002-1554-185X $\quad{ }^{2}$ https://orcid.org/0000-0002-0587-7261 


\section{Introduction}

Bioactive compounds in plants have been used against viral diseases for a long time. Some of these phytochemicals have antioxidant, anti-allergic and anti-inflammatory properties (Bhushan et al., 2020) and also modulate the functions of the receptors and enzymes (Carbonell-Capella et al., 2015). Plant extracts can be used for the preparation of peptides/proteins for medical purpose (Adhikari et al., 2020). Mediterranean people use Cistus species for the treatment of skin diseases, digestive problems (Papaefthimiou et al., 2014) and also as anti-inflammatory (Attaguile et al., 2000). Cistus incanus aqueous solutions contain important bioactive compounds such as rutin, gallic acid, flavonoid (quercetin, kaempferol, glycoside), catechin, epicatechin, gallocatechin (Dimcheva and Karsheva, 2017). It is recorded by several studies that Cistus incanus extraxts have antibacterial and antifungal activity (Simeray et al., 1982; Chinou et al., 1994; Bouamama et al., 1999; Hannig et al., 2008; Barrajón-Catalán et al., 2010; Barros et al., 2013; Wittpahl et al., 2015;) and anti-cancer (Chinou et al., 1994; Dimas et al., 1998; Dimas et al., 2006; Hatziantoniou et al., 2006; BarrajónCatalán et al., 2010; Skoric et al., 2012), also protective effects against DNA cleavage in cell culture (Attaguile et al., 2000). Therefore, anti-influenza virus activities in mice (Droebner et al., 2007; Ehrhardt et al., 2007; Kalusa et al., 2009) and antiviral activity against HIV and Filoviruses (Rebensburg et al., 2016) of Cistus incanus were confirmed.

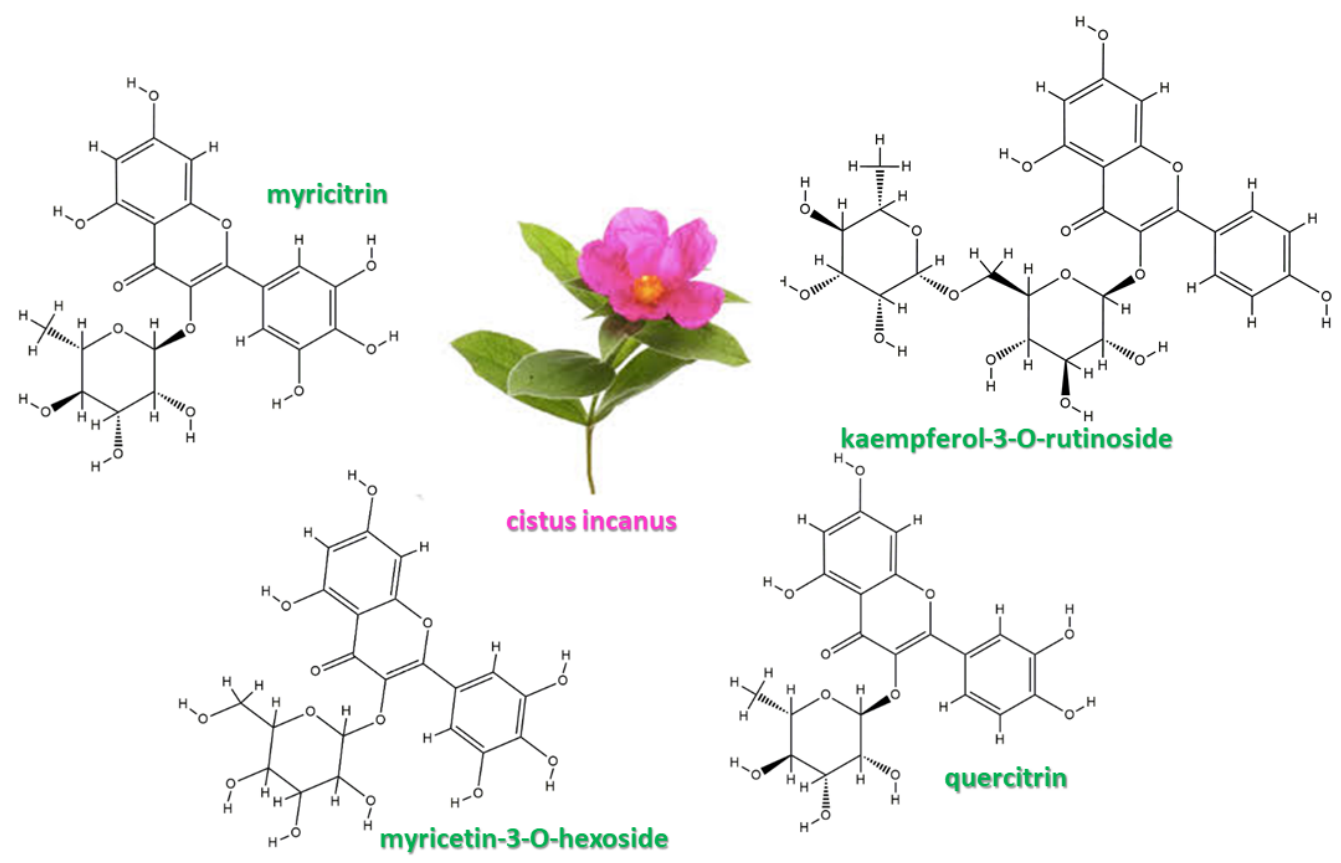

Figure 1. Cistus incanus and four active bio-structures encoded by Gori et al.

COVID-19, the largest pandemic ever seen by this generation, continues to affect all the world. WHO reported 240.061.454 confirmed cases of COVID-19, including 4.887.600 [18.10.2021] 
(https://covid19.who.int/). Since coronavirus disease causes Severe Acute Respiratory Syndrome (SARS), this new virus has been defined as Severe Acute Respiratory Syndrome Coronavirus-2 (SARS-CoV-2) (Peiris et al., 2004; Furukawa et al., 2020). It has been determined that coronaviruses are a non-structural protein processed by two proteases, main protease, and papain-like protease (Gao et al., 2021; Freitas et al., 2020). Papain-like protease (PLP) and main protease (Mpro) regulates the replication and the transcription of the virus and (Capasso et al., 2021; Shin et al., 2020).

Humanity's struggle with coronavirus is continued by vaccination. The total of 6.495.672.032 vaccine doses as of 13 October 2021 have been administered (https://covid19.who.int/). However, the studies have to focus on the detection of new drug molecules without any retardation. The SARSCoV-2 vaccines obtained by encoding the virus will not be suitable for the treatment of coronavirus disease in the future, since the limited efficiency duration of the vaccines and the problems about the virus mutations (Lipsitch and Dean, 2020; Chen et al., 2021).

Drug studies begin with analyzing the activity of natural products (Behl et al., 2021). Later, the isolated active molecules are modified by organic methods and more effective molecules are synthesized (Adhikari et al., 2020). If money, labor, and time opportunities are considered, it does not possible to examine the various bioactivities of each active molecule and modified active molecules. In addition, it is very important to have foresights about more active molecules in the pandemic process we are experiencing. The molecular docking is the most commonly used method for analyzing the activity of structure-based drugs (Contreras-Puentes and Alvíz-Amador, 2020; Wua et al., 2020; Shawky et al., 2020). It provides to obtain important information about the binding regions of target molecules with ligands. In the fight against COVID-19, the analysis of molecules with some known activities has been primarily evaluated. Kandeel and Al-Nazawi (2020) analyzed many molecules which approved by the FDA with PLP in SARS-CoV-2. In addition, the anti-covid activity of many newly synthesized molecules has been frequently examined by molecular docking studies (Liang et al., 2021). Also, many studies have been examined the effects of phytochemicals in various plants against coronavirus (Ali and Kunugi, 2021; Antonio et al., 2021; Alfaro, 2020; Gori, 2016). H-bond interactions with Glu167, Tyr171, Met208 and Tyr268 were determined by molecular docking methods in olea europaea, cichorium intybus, and marrubium vulgare, which have the highest docking scores (Kandeel and Al-Nazawi, 2020). In addition, the H-bonds of cynara scolymus with Asn156, Gly163, Ser170 were determined (Kandeel and Al-Nazawi, 2020; Osipiuk et al., 2021).

Fractional analysis of Cistus incanus was performed by Gori et al. (2016) by HPLC-DADMS/MS method. The highest active ingredients in the plant were flavanol derivative myricetin 3-Ohexoside, myricitrin, quercitrin, and kaempferol 3-O-rutinoside. Myricetin 3-O-hexoside and myricitrin are members of the cistus subgenus. In fragmentation, while myricetin 3-O-hexoside came 
in 24.5 minutes at $\mathrm{m} / \mathrm{z} 479$, myricitrin was detected in 25.6 minutes at $\mathrm{m} / \mathrm{z} 463$. Quercitrin is the active ingredient in m/z 447 and kaempferol 3-O-rutinoside is in m/z 593 (Gori et al., 2016).

In the drug research, it is important to examine the protein-ligand binding properties of viral proteins. In this study, the papain-like protease and main protease inhibition activity of quercitin, myricitrin, myricetin-3-O-hexoside, and kaempferol-3-O-rutinoside molecules that can be obtained from Cistus incanus were investigated by molecular docking method. To the best of our knowledge, the activity of the myricetin-3-O-hexoside molecule against COVID-19 disease hasn't been studied.

\section{Materials and Methods}

Content analysis of the plant Cistus incanus was performed by Gori et al. HPLC-DAD-MS / MS was used for detailed analysis of components obtained from crude ethanolic leaf extract. The most common components according to the peak length were determined as 3-O-hexoside, myricitrin, quercitrin and kaempferol 3-O-rutinocide (Gori et al., 2016). Papain-like protease inhibition capacity of these active molecules has been in-silico determined. The $3 \mathrm{~d}$ structures of the active molecules were downloaded from the National Library of Medicine (National Center of Biotecnology Information; https://pubchem.ncbi.nlm.nih.gov/). The crystal structure of Papain-like proteas with PDB ID: 6w9c and main protease with PDB ID: 6lu7 were taken from Protein Data Bank (https://www.rcsb.org/ ) (Osipiuk et al., 2021; Jin et al., 2020; Trott and Olson, 2010). Water molecules were removed from the crystal and only polar hydrogens were added. The protein target molecule was saved as pdbqt and imported into the AutoDockTools. Kollman Charges and Lamarkian Genetic Algorithms were used in calculations. BIOVIA Discovery Studio Visualizer was used to visualize molecules and binding interactions (https://discover.3ds.com/discovery-studio-visualizer ) (Holt et al., 2008; Li et al., 2021).

\section{Findings and Discussion}

PLP is a proteolytic enzyme effective in host innate immunity and viral replication since it can be used as a target molecule as a coronavirus inhibitor (Su et al., 2021; Reddy et al., 2021; Banerjee et al., 2020). There is no FDA-approved drug as a PLP inhibitor. Maiti (2020) recorded that the PLP which is encoded from SARS-CoV-2 have active sites such as the labile region consist of Cys189, Cys192, Cys224 and Cys226, and catalytic region consist of Cys111, His272 and Asp286 amino acids and these sites have key functions in viral replication (Banerjee et al., 2020). These regions can be considered as important region for candidate molecules. It has been interpreted that the inhibition of the Cys amino acid in the catalytic region by sulfur-based molecules can provide dysfunction of PLP 
and stop viral replication. The 6w9c coded PLP crystal structure was released in April 2020 (Osipiuk et al., 2021). In molecular docking studies with this crystal structure, the interactions with the region formed by amino acids such as Leu162, Val202, Met206 and Met208 were recorded mostly. However, the interactions with polar amino acids such as Ser170 and Asn156 are also remarkable (Saakre et al., 2021; Banerjee et al., 2021).

Table 1. Active site analysis of SARS CoV-2 papain-like protease (PDB ID:6w9c) with quercitrin, myricitrin, myricetin-3-O-hexoside and kaempferol 3-O-rutinoside (red: H-bond, green: pi-pi T-shaped interactions, blue: Van der Waals interactions, pink: pi-alkyl, orange: pi-cation))

\begin{tabular}{|c|c|c|}
\hline Molecules & $\begin{array}{l}\text { Bind. } \\
\text { Aff.* }\end{array}$ & Amino Acids Residue \\
\hline \multicolumn{3}{|r|}{ 6w9c } \\
\hline kaempferol 3-O-rutinoside & -4.83 & $\begin{array}{l}\text { Asp76, Glu167, Thr74, Cys155, Tyr171, His175, His73, Ser78, Phe79, } \\
\text { Ala153, Tyr154, Asn156, Lys157, Glu161, Gln174 }\end{array}$ \\
\hline myricetin-3-O-hexoside & -2.61 & $\begin{array}{l}\text { Asp76, Arg82, Ala153, Asn156, Gln174, Tyr171, His175, Thr74, Ser78, } \\
\text { Phe79, Tyr154, Cys155 }\end{array}$ \\
\hline myricitrin & -3.46 & $\begin{array}{l}\text { Asp76, Arg82, Asn156, Tyr171, Thr74, Ser78, Phe79, Tyr154, Gln174, } \\
\text { His175 }\end{array}$ \\
\hline quercitrin & -3.91 & $\begin{array}{l}\text { Asp76, Arg82, Ala153, Tyr154, Asn156, Tyr171, Thr74, Phe79, } \\
\text { Cys155, Gln174, His175 }\end{array}$ \\
\hline \multicolumn{3}{|r|}{ 6lu7 } \\
\hline kaempferol 3-O-rutinoside & -3.95 & $\begin{array}{l}\text { Lys5, Glu288, Phe3, Met6, Trp207, Gly283, Ser284, Ala285, Leu286, } \\
\text { Phe291, Leu282, Arg4 }\end{array}$ \\
\hline myricetin-3-O-hexoside & -4.79 & $\begin{array}{l}\text { Lys5, Trp207, Ile281, Leu282, Glu288, Phe3, Met6, Gly283, Ser284, } \\
\text { Leu286, Phe291, Arg4 }\end{array}$ \\
\hline myricitrin & -5.34 & $\begin{array}{l}\text { Gln127, Lys137, Gly138, Asp289, Tyr126, Ser139, Leu286, Leu287, } \\
\text { Glu288, Lys5, Arg131, Glu290, Cys128 }\end{array}$ \\
\hline quercitrin & -5.50 & $\begin{array}{l}\text { Lys5, Trp207, Leu282, Glu288, Phe3, Met6, Ala7, Ile281, Gly283, } \\
\text { Ser284, Leu286, Arg4 }\end{array}$ \\
\hline
\end{tabular}

* Binding Affinity in kcal/mol.

Many H-bonds were identified for this study. H-bonds with Asp76, Glu167, Thr74, Cys155, and Tyr171 amino acids for kaempferol 3-O-rutinoside were recorded with the binding energy of $4.83 \mathrm{kcal} / \mathrm{mol}$. In addition, it is also expected of contribution of many Van der Waals interactions and Pi-pi T-shaped interaction with His175 to the binding energy calculated for kaempferol 3-Orutinoside. To the best of our knowledge, the activity of the myricetin-3-O-hexoside against COVID19 has never been studied before. Although the binding energy of the myricetin-3-O-hexoside is relatively low, H-bonds with Asp76, Arg82, Ala153, Asn156, Gln174, Tyr171, and His175 are noteworthy besides many Van der Waals interactions. Myricitrin interacted with approximately the same region of the target molecule with $-3.46 \mathrm{kcal} / \mathrm{mol}$ binding affinity. $\mathrm{H}$-bonds of myricitrin were recorded with Asp76, Arg82, Asn156, and Tyr171. The interactions of the quercitrin with nearly similar amino acids can be examined in Table 1 and Fig 2. The docking score of the quercitrin was calculated as $-3.91 \mathrm{kcal} / \mathrm{mol}$. 


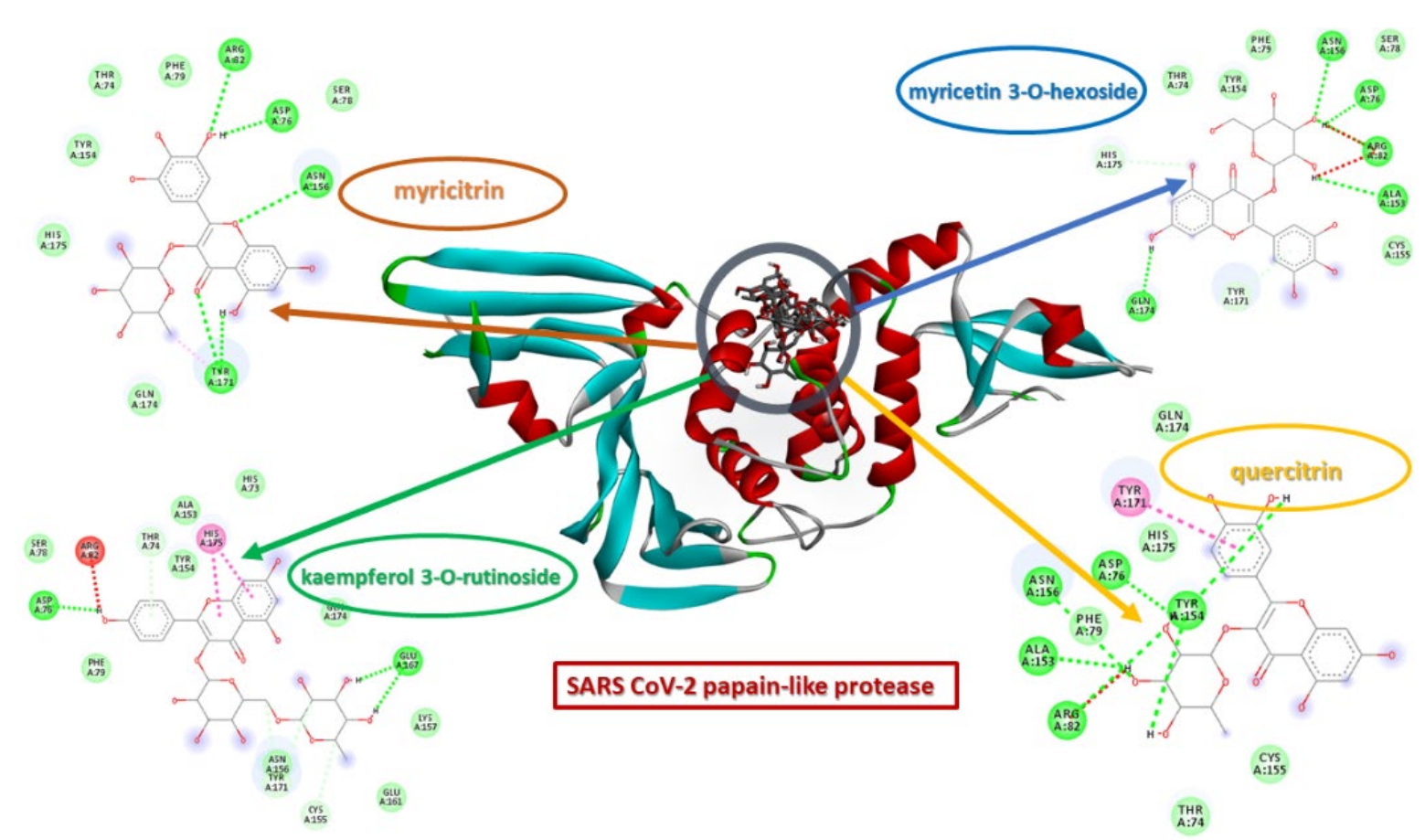

Figure 2. Interaction Residues and types of quercitrin, myricitrin, myricetin-3-O-hexoside and kaempferol 3-O-rutinoside with Papain-like Protease

COVID-19 main protease which is a key enzyme for fighting against global pandemic has an important role in mediating viral transcription and replication. Since it is also an attractive target for SARS CoV-2 researches, many plant-derived chemicals were analyzed for inhibition of potential against this enzyme. Sherif et al. evaluated curcumin derivatives and recorded good interactions (Sherif et al., 2021). Chebaibi et al. also evaluate the inhibitory effect of flavonoids and polyphenols of citrus limon and garlic and suggested some phytochemicals such as ellagic acid and narirutin as an inhibitor of SARS CoV-2 (Chebaibi et al., 2021). Many other phytochemicals also analyzed for main protease inhibition activities by Sisakht et al (Sisakht et al., 2021). Chhetri et al. synthesized and characterized new azo imidazole derivatives and searched for their inhibitor activity against COVID19 main protease (Chhetri et al., 2021). $\mathrm{Co}(\mathrm{II}), \mathrm{Ni}(\mathrm{II})$, and $\mathrm{Cu}(\mathrm{II})$ deoxycholate complexes also analyzed wit molecular docking methods by Refat et al. and high binding affinities were recorded that could be a signal for possible anti-viral activity (Refat at al., 2021).

All the active molecules studied in this research interacted nearly the same region of the main protease crystal. Relatively higher binding affinities were calculated than the that of PLP. Quercitrin has the best binding affinity as $-5.50 \mathrm{kcal} / \mathrm{mol}$, and kaempferol 3-O-rutinoside, myricetin-3-O-hexoside, and myricitrin have $-3.95 \mathrm{kcal} / \mathrm{mol},-4.79 \mathrm{kcal} / \mathrm{mol}$, and $-5.34 \mathrm{kcal} / \mathrm{mol}$ binding energies, respectively. Quercitrin has four H-bonds with Lys5, Trp207, Leu282, and Glu288 while myricitrin interacted with Gln127, Lys137, Gly138, and Asp289 for H-bonds. All other interaction types and details can be examined in Table1 and Figure 3. 


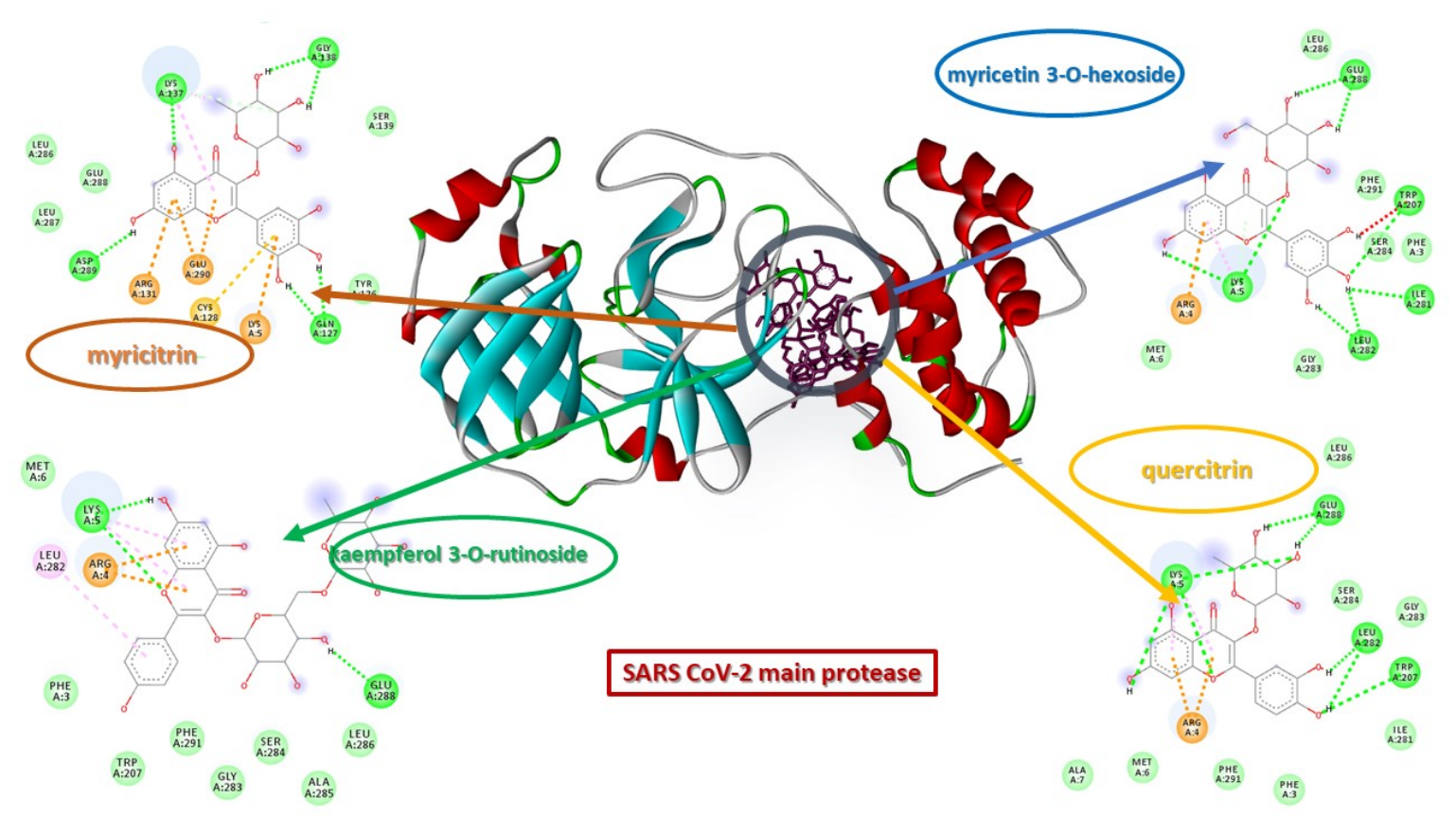

Figure 3. Interaction Residues and types of quercitrin, myricitrin, myricetin-3-O-hexoside and kaempferol 3-O-rutinoside with Main Protease

\section{Conclusions and Recommendations}

Phytochemicals are frequently used in the treatment of various diseases. Pharmaceutical companies often convert the results obtained from the activity analysis of phytochemicals into commercial products. Phytochemicals, whose activity is often confirmed, are converted into more active forms by synthetic methods. One of the herbals whose many activities have been studied is Cistus incanus. The antibacterial and anti-viral activity of both the flower and the leaves of this plant has been confirmed by several studies. The antiviral activity of different forms of active phytochemicals obtained from the leaf of this plant is well known. In this study, the activity of myricetin 3-O-hexoside, myricitrin, quercitrin and kaempferol 3-O-rutinocide molecules, which were determined as most common agents in Cistus incanus, against SARS CoV-2 were investigated. For this purpose, the inhibition activities of molecules against papain-like protease and main protease were analyzed by molecular docking method. Although the binding affinity results of the molecular docking are acceptable, the detected H-bonds are promising. It could advice for future studies to analyze of the different forms of these structures.

\section{Authors' Contributions}

All authors contributed equally to the study. 


\section{Statement of Conflicts of Interest}

There is no conflict of interest between the authors.

\section{Statement of Research and Publication Ethics}

The author declares that this study complies with Research and Publication Ethics.

\section{References}

Adhikari, B., Marasini, B. P., Rayamajhee, B., Bhattarai, B. J., Lamichhane, G., Khadayat, K., Adhikari, A., Khanal, S., and Parajuli,N. (2020). Potential roles of medicinal plants for the treatment of viral diseases focusing on COVID-19: A review. Phytotherapy Research, 35, 1298-1312.

Alfaro, M., Alfaro, I., \& Angel, C. (2020). Identification of potential inhibitors of SARS-CoV-2 papain-like proteasefrom tropane alkaloids from Schizanthus porrigens: A moleculardocking study. Chemical Physics Letters, 761, 138068.Tallei, T. E., Tumilaar, S. G., Niode, N. J., Fatimawali, Kepel, B. J., Idroes, R., Effendi, Y., Sakib, S. A., Emran, T. B. (2020). Potential of plant bioactive compounds as SARSCoV-2 main protease (Mpro) and spike (S) glycoprotein inhibitors: A molecular docking study". Scientifica, Article ID 6307457.

Ali, A. M., and Kunugi, H. (2021). Propolis, bee honey, and their components protect against coronavirus disease 2019 (COVID-19): A Review of in silico, in vitro, and clinical studies", Molecules, 26, 1232.

Antonio, A. S., Wiedemann, L. S. M., and Veiga-Junior, V. F. (2020). Natural products' role against COVID19. RSC Advances, 10, 23379.

Attaguile, G., Russo, A., Campisi, A., Savoca, F., Acquaviva, R., Ragusa, N, and Vanella, A. (2000). Antioxidant activity and protective effect on DNA cleavage of extracts from Cistus incanus L. and Cistus monspeliensis L. Cell Biology and Toxicology, 16, 83 - 90.

Banerjee, A., Santra, D., \& Maiti,S. (2020). Energetics and IC50 based epitope screening in SARS CoV-2 (COVID 19) spike protein by immune informatic analysis implicating for a suitable vaccine development. Journal of Translational Medicine, 18, 281.

Banerjee, R., Perera, L., and Tillekeratne, L. M. V. (2021). Potential SARS-CoV-2 main protease inhibitors. Drug Discovery Today, 26(3).

Barrajón-Catalán, E., Fernández-Arroyo, S., Saura, D., Guillén, E., Fernández- Gutiérrez, A., SeguraCarretero, A. (2010). Cistaceae aqueous extracts containing ellagitannins show antioxidant and antimicrobial capacity, and cyto- toxic activity against human cancer cells. Food Chemistry and Toxicology, 48. 2273-2282. doi: 10.1016/j.fct.2010.05.060.

Barros, L., Dueñas, M., Alves, C. T., Silva, S., Henriques, M., Santos-Buelga, C. (2013). Antifungal activity and detailed chemical characterization of Cistus ladanifer phenolic extracts. Industrial Crops and Products, 41. 41-45. doi: 10.1016/j.indcrop.2012.03.038.

Behl, T., Rocchetti, G., Chadha, S., Zengin, G., Bungau, S., Kumar, A., Mehta, V., Uddin, S., Khullar, G., Setia, D., Arora, S., Sinan, K. I., Ak, G., Putnik, P., Gallo,M., and Montesano, D. (2021). Phytochemicals from plant foods as potential source ofantiviral agents: an overview. Pharmaceuticals, $14,381$.

Bhushan, I., Sharmaa, M., Mehtaa, M., Badyala, S., Sharmab, V., Sharmab, I., Singha, S., Sistlac, H. (2020). Bioactive compounds and probiotics-a ray of hope in COVID-19 management. Food Science and Human Wellness, 10, 131-140.

Bouamama, H., Villard, J., Benharref, A., and Jana, M. (1999). Antibacterial and antifungal activities of Cistusincanus and C. monspeliensis leaf extracts. Thérapie 54, 731-733.

Capasso, C., Nocentini, A., \& Supuran, C. T. (2021) Protease inhibitors targeting the main protease and papainlike protease of coronaviruses. Expert Opinion on Therapeutic Patents, 31(4), 309-324

Carbonell-Capella, J. M., Buniowska, M., Esteve, M.J. (2015). Effect of Stevia rebaudiana addition on bioaccessibility of bioactive compounds and antioxidant activity of beverages based on exotic fruits 
mixed with oat following simulated human digestion. Food Chemistry, 184, 122-130. https://doi.org/10.1016/j.foodchem.2015.03.095.

Chebaibi, M., Bousta, D., Gonçalves, R. F. B., Hoummani, H., \& Achour, S. (2021). Medicinal Plants Against Coronavirus (SARS-COV-2) in Morocco Via Computational Virtual Screening Approach, Research Square, DOI: https://doi.org/10.21203/rs.3.rs-679827/v1

Chen, j., Gao, K., Wang, R., and Wei, G. W. (2021). Prediction and mitigation of mutation threats to COVID19 vaccines and antibody therapies. Chemical Science, DOI: 10.1039/D1SC01203G (Edge Article)

Chhetri, A., Chettri, S., Rai, P., Mishra, D. K., Sinha, B., \& Brahman, D. (2021). Synthesis, characterization and computational study on potential inhibitory action of novel azo imidazole derivatives against COVID-19 main protease (Mpro: 6LU7). Journal of molecular structure, 1225, 129230.

Chinou, F., Demefzos, C., Harvala, C., Roussakis, C., and Verbist, J. F. (1994). Cytotoxic and antibacterial labdane-type diterpenes from the aerial parts of Cistus incanus subsp. Creticus. Planta Medica, 60 (1), 34-36.

Contreras-Puentes, N., and Alvíz-Amador, A. (2020). Virtual screening of natural metabolites and antiviral drugswith potential inhibitory activity against 3CL-PRO and PL-PRO. Biomedical and Pharmacology Journal, 13(2), 933-941.

Dimas, K., Demetzos, C., Marsellos, M., Sotiriadou, R., Malamas, M., and Kokkinopoulos, D. (1998). Cytotoxic activity of labdane type diterpenes against human leukemic cell lines in vitro. Planta Medica, 64. 208-211. doi:10.1055/s- 2006-957410

Dimas, K., Papadaki, M., Tsimplouli, C., Hatziantoniou, S., Alevizopoulos, K., Pantazis, P. (2006). Labd-14ene-8,13-diol (sclareol) induces cell cycle arrest and apoptosis in human breast cancer cells and enhances the activity of anti-cancer drugs. Biomedicine \& Pharmacotherapy,60. 127-133. doi: 10.1016/j.biopha.2006.01.003

Dimcheva, V., and Karsheva, M. (2017). Antioxidant activity and polyphenolic content of the bulgarian wild herb Cistus incanus L. stored under different conditions. Journal of Chemical Technology and Metallurgy, 52 (5). 781-790.

Droebner, K., Ehrhardt, C., Poetter, A., Ludwig, S., and Planz, O. (2007). CYSTUS052, a polyphenol-rich plant extract, exerts anti-influenza virus activity in mice. Antiviral Research, 76. 1-10. doi:10.1016/j.antiviral.2007.04.001

Ehrhardt, C., Hrincius, E. R., Korte, V., Mazur, I., Droebner, K., Poetter, A. (2007). A polyphenol rich plant extract, CYSTUS052, exerts anti influenza virus activity in cell culture without toxic side effects or the tendency to induce viral resistance. Antiviral Research, 76. 38-47. doi:10.1016/j.antiviral.2007.05.002

Freitas, B. T., Durie, I. A., Murray, J., Longo, J. E., Miller, H. C., Crich, D., Hogan,R. J., Tripp, R. A., and Pegan, S. D. (2020). Characterization and noncovalent inhibition of the deubiquitinase and deisgylase activity of sars-cov-2 papain-like protease. ACS Infectious Diseases, 6(8), 2099-2109.

Furukawa, N. W., Brooks, J. T., and Sobel, J. (2020). Evidence supporting transmission of severe acute respiratory syndrome coronavirus 2 while presymptomatic or asymptomatic. Emerging Infectious Diseases Journal, 26(7), e201595.

Gao, X., Qin, B., Chen, P., Zhu, K., Hou, P., Wojdyla, J. A., Wang, M., and Cui, S. (2021). Crystal structure of SARS-CoV-2 papain-like protease. Acta Pharmaceutica Sinica B, 11(1), 237-245.

Gori, A., Ferrini, F., Marzano, M. C., Tattini, M., Centritto, M., Baratto, M. C., Pogni R., and Brunetti, C. (2016). Characterisation and antioxidant activity of crude extract and polyphenolic rich fractions from C. incanus leaves. International Journal of Moleculer Science, 17, 1344.

Hannig, C., Spitzmüller, B., Al-Ahmand, A., Hannig, M. (2008). Effects of Cistus-tea on bacterial colonization and enzyme activities of the in-situ pellicle. Journal of Dentistry, 36. 540-545.

Hatziantoniou, S., Dimas, K., Georgopoulos, A., Sotiriadou, N., and Demetzos, C. (2006). Cytotoxic and antitumor activity of liposome-incorporated sclareol against cancer cell lines and human colon cancer xenografts. Pharmacoogical Research, 53. 80-87. doi:10.1016/j.phrs.2005.09.008

Holt, P. A., Chaire, J. B., and Trent, J. O. (2008). Molecular docking of intercalators and groove-binders to nucleic acids using autodock and surflex. Journal of Chemical Information and Modeling, 48(8), 16021615.

Jin, Z., Du, X., Xu, Y., Deng, Y., Liu, M., Zhao, Y., Zhang, B., Li, X., Zhang, L., Peng, C., Duan, Y., Yu, J., Wang, L., Yang, K., Liu, F., Jiang, R., yang, X., You, T., Liu, X., Yang, X., Bai, F., Liu, H., Liu, X., Guddat, L. W., Xu, W., Xiao, G., Qin, C., Shi, Z., Jiang, H., Rao, Z., Yang, H. \& Yang, H. (2020). Structure of M pro from SARS-CoV-2 and discovery of its inhibitors. Nature, 582(7811), 289-293. 
Kalusa,U., Grigorova, A., Kadeckib, O., Jansenc, J. P., Kiesewettera, H., Radtkea, H. (2009). Cistus incanus (CYSTUS052) for treating patients with infection of the upper respiratory tract a prospective, randomized, placebo-controlled clinical study. Antiviral Research, 84. 267-271.

Kandeel, M., and Al-Nazawi, M. (2020). Virtual screening and repurposing of FDA approved drugs against COVID-19 main protease. Life Sciences Volume, 251, 117627.

Li, D., Luan, J., and Zhang, L. (2021). Molecular docking of potential SARS-CoV-2 papain-like proteaseinhibitors. Biochemical and Biophysical Research Communications, 538, 72-79.

Liang, C., Hui, N., Liu,Y., Qiao, G., Li, J., Tian, L., Ju, X., Jia, M., Liu, H., Cao, W., Yu, P., Li, H., \& Ren, X. (2021). Insights into forsythia honeysuckle (Lianhuaqingwen) capsules: A Chinese herbal medicine repurposed for COVID-19 pandemic. Phytomedicine Plus, 1, 100027.

Lipsitch, M., and Dean, N. E. (2020). Understanding COVID-19 vaccine efficacy. Science, 370, 6518, $763-$ 765.

Maiti, B. K. (2020). Can papain-like protease inhibitors halt SARS-CoV-2 replication?. ACS Pharmacology \& Translational Science, 3(5), 1017-1019.

Osipiuk, J., Jedrzejczak, R., Tesar, C., Endres, M., Stols, L., Babnigg, G., Kim, Y., Michalska, K., Joachimiak, A. The crystal structure of papain-like protease of SARS CoV-2. Center for Structural Genomics of Infectious Diseases (CSGID), To be published.

Papaefthimiou, D., Papanikolaou, A., Falara, V., Givanoudi, S., Kostas, S., and Kanellis, A. K. (2014) . Genus Cistus: a model for exploring labdane type diterpenes' biosynthesis and a natural source of high value products with biological, aromatic, and pharmacological properties. Frontiers in Chemistry, 2(35). doi: 10.3389/fchem.2014.00035

Peiris, J. S. M., Guan, Y., and Yuen, K. Y. (2004). Severe acute respiratory syndrome. Nature Medicine, 10, $88-97$.

Rebensburg, S., Helfer, M., Schneider, M., Koppensteiner, H., Eberle, J., Schindler, M., ... \& Brack-Werner, R. (2016). Potent in vitro antiviral activity of Cistus incanus extract against HIV and Filoviruses targets viral envelope proteins. Scientific Reports, 6(1), 1-15.

Reddy. M. P., Makhal, P., and Rao, K. V. (2021). Potential herbal drugs and phytochemicals to minimize the risk of COVID-19: A review. Journal of Pharmacognosy and Phytochemistry, 10(1), 670-675.

Refat, M. S., Bakare, S. B., Altalhi, T. A., Alam, K., \& Al-Hazmi, G. H. (2021). Synthesis and spectroscopic interpretations of $\mathrm{Co}$ (II), $\mathrm{Ni}$ (II) and $\mathrm{Cu}$ (II) decxycholate complexes with molecular docking of COVId19 protease. Polish Journal of Chemical Technology, 23(2), 54-59.

Saakre, M., Mathew D., and Ravisankar, V. (2021). Perspectives on plant flavonoid quercetin-based drugs for novel SARS-CoV-2. Beni-Suef University Journal of Basic and Applied Sciences.

Shawky, E., Nada, A. A., and Ibrahim, R. S. (2020). Potential role of medicinal plants and their constituents in the mitigation of SARS-CoV-2: identifying related therapeutic targets using network pharmacology and molecular docking analyses. RSC Advances, 10, 27961.

Sherif, Y. E., Sayed, A. H., \& Lotfy, M. (2021). Antiviral Effect of Curcuminoids and Curcumin Derivatives Against Coronavirus (Sars-Cov-2) Predicted Using Molecular Docking Approach. Egyptian Academic Journal of Biological Sciences. C, Physiology and Molecular Biology, 13(2), 47-62.

Shin, D., Mukherjee, R., Grewe, D., Bojkova, D., Baek, K., Bhattacharya,A., Schulz, L., Widera, M., Mehdipour, A. R., Tascher, G., Geurink, P. P., Wilhelm, A., Noort, G. J. H., Ovaa, H., Müller, S., Knobeloch, K. P., Rajalingam, K., Schulman,B. A., Cinatl, J., Hummer, G., Ciesek, S. \& Dikic, I. (2020). Papain-like protease regulates SARS-CoV-2 viral spread and innate immunity, Nature volume, $587,657-662$.

Simeray, J., Chaumont, J. P., Bevalot, F. \& Vaquette, I. (1982). Les propietes antifongiques des Cistae"es et plus particulie"rement de Cistus Laurifolius L.: role des tanins non hydrolysables. Fitoterapia, 53(43). 8.

Sisakht, M., Mahmoodzadeh, A., \& Darabian, M. (2021). Plant-derived chemicals as potential inhibitors of SARS-CoV-2 main protease (6LU7), a virtual screening study. Phytotherapy Research, 35(6), $3262-$ 3274.

Skori'c, M., Todorovi'c, S., Gligorijevi'c, N., Jankovi'c, R., Živkovi'c, S., Risti'c, M. (2012). Cytotoxic activity of ethanol extracts of in vitro grown Cistus creticus subsp. creticus L. on human cancer cell lines. Industrial and Crops Products. 38. 153-159. doi: 10.1016/j.indcrop.2012.01.017

Su, W., Chen, P., Yang, Z., Zhong, N., Ma, Q., Zeng, X., Zhang, J., Wang, Y., \& Li, P. (2021). Network pharmacology integrated molecular docking reveals the potential of hypericum japonicum thunb. ex murray against COVID-19. Biotechnology \& Biotechnological Equipment, 35(1), 453-461. 
Trott, O., and Olson, A. J. (2010). AutoDock Vina: Improving the speed and accuracy of docking with a new scoring function, efficient optimization, and multithreading. Journal of Computational Chemistry, 31(2), 455-461.

Wittpahl, G., Kölling-Speer, I., Basche, S., Herrmann, E., Hannig, M., Speer, K., \& Hannig, C. (2015). The polyphenolic composition of Cistus incanus herbal tea and its antibacterial and anti-adherent activity against Streptococcus mutans. Planta Medica, 81(18), 1727-1735.

Wua, C., Liu, Y., Yang, Y., Zhang, P., Zhong, W., Wang, Y., Wang, Q., Xu,Y., Li,Xingzhou Li, M., Zheng, M., Chen, L., \& Li, H. (2020). Analysis of therapeutic targets for SARS-CoV-2 and discovery of potential drugs by computational methods. Acta Pharmaceutica Sinica B, 10(5), 766-788. 